\title{
RANCANG BANGUN ALAT SIMULATOR PNEUMATIC DUA SILINDER KATUP SELENOID TUNGGAL
}

\author{
ALI ROSYIDIN \\ Program Studi Teknik Mesin.Fakultas Teknik, \\ Universitas Muhammadiyah Tangerang \\ Jl. Perintis Kemerdekaaqn I, No.33, Cikokol Kota Tangerang Banten 15118, Indonesia \\ E-mail: rosyidinali90@gmail.com
}

\begin{abstract}
ABSTRAK
Dalam perkembangan teknologi yang semakin pesat, mahasiswa teknik dalam proses pembelajaran dengan waktu yang sangat singkat dituntut untuk memahami materi secarah utuh dan problem solving, sehingga lulus nanti menjadi seorang engineer yang mampu bersaing di dunia pekerjaan, Pneumatic bekerja berdasarkan tekanan udara, digunakan untuk menggerakan sebuah cylinder kerja. Cylinder kerja inilah yang nantinya mengubah tenaga atau tekanan udara tersebut menjadi tenaga mekanik yang membantu manuasia dalam pekerjaannya. Rancang bangun alat praktikum pneumatic dua silinder katup solenoid Tunggal ini hanya sebagai bentuk simulator/alat praga dan digunakan untuk kegiatan belajar khususnya di dunia pendidikan, untuk meningkatkan imajinasi dan penerapan ilmu dalam dunia kerja. Udara kempa yang disalurkan dengan membuka katup pada service unit, (menggunakan tekanan udara yang telah di tentukan), kemudian menekan tombol katup pneumatic (katup pengarah) hingga udara kempa masuk ke dalam tabung pneumatic (silinder pneumatic kerja tunggal) dan akhirnya piston bergerak maju mundur. Bahan Utama pembuatan Rancang bangun alat simulator silinder pnumatik tipe BSC 32x50 2 buah, Selenoid tipe V5222-084 pressure 0,15-0,8 Mpa 2 buah, Shuttle Valve type Ks-02 satu buah, Push Button tipe M32-08S1B pressure: 0-0,8 Mpa satu buah, Lever Valve tipe M32-08S2 satu buah, Regulator ukuran 14 satu buah, selang $6 \mathrm{~mm} 6 \mathrm{~m} 2$ buah,, Nepel ukuran $6 \mathrm{~mm} 26$ buah dan Elektrik Selenoid 4V10-08 Pressure1,5-8kg 1 buah.
\end{abstract}

Kata Kunci: Simulator, Pneumatic, Dua Silinder, Katup Selenoid Tunggal.

\section{PENDAHULUAN}

Seiring dengan Perkembangan teknologi seorang mahasiswa teknik dalam proses pembelajaran di tuntut untuk menjadi seorang engineer yang mampu bersaing di dunia pekerjaan, perkembangan ilmu dan teknologi yang sangat pesat tentunya semakin mempermudah manusia dalam menjalani pekerjaannya, pengaplikasian ilmu dan pengalaman dapat disatukan untuk memberikan para mahasiswa sebuah wawasan, sehingga nantinya dapat di aplikasikan pada dunia pekerjaan.

Alat simulasi pneumatic mambantu para mahasiswa untuk meningkatkan imajinasi dalam merangkai rangkaian sistem pneumatic, serta bisa mengetahui cara kerja mekanisme sistem pneumatic dan fungsi opera- sional komponen-komponen dari sistem pneumatic tersebut.

Alat simulasi pneumatic luas sekali pengaplikasiaannya yang berkembang pada bidang industri, pneumatic yang pada dasaranya alat pembantu dalam pekerjaan manusia sering kali memberikan fungsi yang berbeda pada setiap pekerjanannya namun memiliki fungsi yang sama yaitu membantu sebuah pekerjaan.

Tujuan penelitian ini sebagai pengetahuan serta pengalaman tentang proses rancang bangun alat simulator/alat praktikum pneumatic dua silinder katup selenoid tunggal, karena masih minimnya penjualan alat simulator/alat peraga pneumatic dipasaran serta sangat mahalnya harga Simulator pneu- 
matic dipasaran. Menyempurnakan alat-alat yang sudah ada

Manfaat yang diharapkan sebagai alat simulator dalam memelajari dan mendalami segala macam permasalahan yang timbul dalam pembuatan alat praktikum pneumatic dua silinder katup selenoid tunggal agar dapat diterapkan dalam bidang Pekerjaan. Memperkuat dan menumbuhkan kemampuan inovasi bagi perguruan tinggi dalam menggali dan meningkatkan kualitas produk. Sebagai bahan kajian kuliah khususnya di program Studi Teknik Mesin dalam mata kuliah bidang Teknik Mesin. Memberikan kontribusi yang positif terhadap pengembangan apl ikasi ilmu dan teknologi, khususnya pada jurusan Teknik Mesin

\section{METODELOGI PENELITIAN \\ 1. Persiapan Penelitian}

Sebelum penelitian dilakukan, terlebih dahulu, melakukan penelitian merancang bentuk dan ukuran pada alat, simulator dan mempersiapkan bahan-bahan dan peralatan-peralatan yang akan digunakan untuk penelitian.

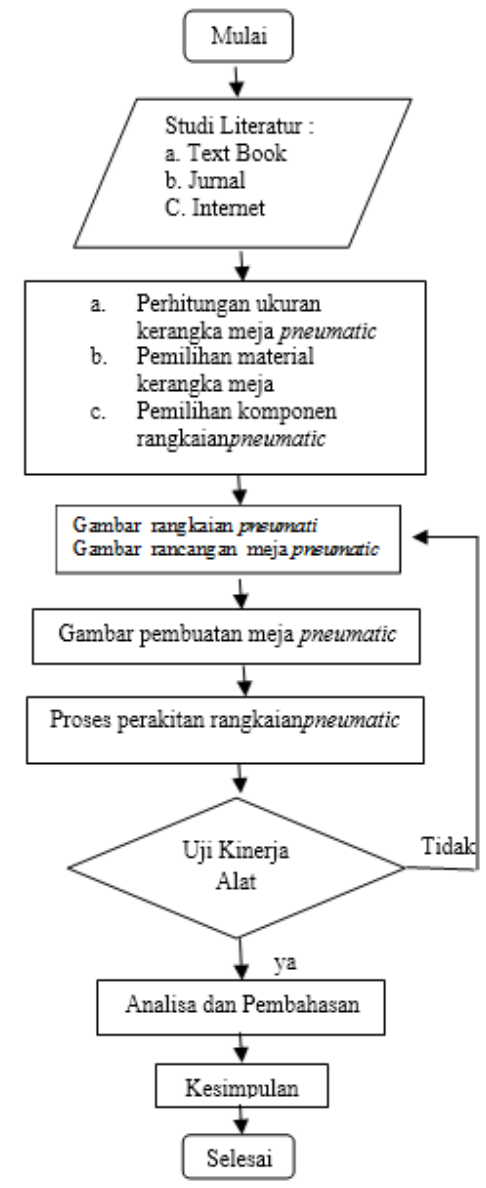

Gambar 1 Diagram Alir Penelitian.

\section{Perancangan Alat Pneumatic}

Selanjutnya membuat rancang bangun alat praktikum pneumatic dengan langkah langkah sebagai berikut:

a) Perancangan desain bentuk rangkaian pneumatic;

b) Pembuatan gambar polah meja serta ditentukan ukurannya;

c) Dipilih bahan yang akan digunakan untuk membuat rangkaian pneumatic;

d) Dilakukan pengukuran terhadap bahanbahan yang akan digunakan dengan ukuran yang telah ditentukan;

e) Potong bahan sesuai dengan ukuran yang telah ditentukan;

f) Dibentuk dan dilakukan pengelasan pada besi siku dan pengeboran untuk membentuk kerangka pada alat; dan

g) Digerinda permukaan yang terlihat kasar karena proses pengerjaan.Dilakukan pengecetan pada rangka guna memperpanjang umur pemakaian alat dan menambahdaya tarik pada alat pneumatic.

\section{Bahan Dan Alat}

a. Kebutuhan Bahan (lihat tabel 1)

Tabel 1 Bahan Utama

\begin{tabular}{|c|c|c|c|c|}
\hline No & Bahan & Ukuran & Satuan & Jumlah \\
\hline 1 & Besi Siku & $\begin{array}{l}\text { Panjang }=6 \mathrm{~m} \\
\text { Tebal }=2 \mathrm{~mm} \\
\text { Lebar }=3 \mathrm{~cm}\end{array}$ & meter & 3 \\
\hline 2 & $\begin{array}{l}\text { Papan kayu dan } \\
\text { melamin }\end{array}$ & $\begin{array}{l}\text { Panjang }=100 \mathrm{~cm} \\
\text { Tebal }=1 \mathrm{~cm} \\
\text { Lebar }=100 \mathrm{~cm}\end{array}$ & $\mathrm{~cm}$ & 1 \\
\hline 3 & Baut dan Mur & M12 & pes & 16 \\
\hline 4 & Roda & kecil & pes & 4 \\
\hline 5 & Silinder & Tipe BSC $32 \times 50$ & pes & 2 \\
\hline 6 & Selenoid & $\begin{array}{l}\text { V5222-084 } \\
\text { presure : } 0,15-0,8 \\
\text { Mpa }\end{array}$ & pes & 2 \\
\hline 7 & Shuttle Valve & Tipe Ks-02 & pes & 1 \\
\hline 8 & Push Button & $\begin{array}{l}\text { M32-08S1B } \\
\text { pressure : } 0-0,8 \\
\text { Mpa }\end{array}$ & pes & 1 \\
\hline 9 & Lever Valve & $\begin{array}{l}\text { M32-08S2 } \\
\text { pressure : 0-0,8 } \\
\text { Mpa }\end{array}$ & pcs & 1 \\
\hline 10 & Regulator & Ukuran 1/4 & pcs & 1 \\
\hline 11 & Selang & $\begin{array}{l}\text { Ukuran } 6 \\
=6 \mathrm{~m}\end{array}$ & pes & 2 \\
\hline 12 & Nepel & Ukuran 6 & pes & 26 \\
\hline 13 & $\begin{array}{l}\text { Elektrik } \\
\text { Selenoid }\end{array}$ & $\begin{array}{l}\mathrm{V} 10-08 \\
\text { Pressure } 1,5-8 \mathrm{~kg}\end{array}$ & pcs & 1 \\
\hline
\end{tabular}

b. Alat yang dibutuhkan sebagai berikut:

1. Las listrik;

2. Mesin bor;

3. Mesin gerinda; 

4. Palu;
5. Obeng;
6. Tang;
7. Kunci pas;
8. Kunci ring;
9. Meteran;
10.Gergaji kayu;
11.Amplas kayu;
12.Penggaris siku;
13.Spidol;
14.Amplas besi.

Selanjutnya membuat alat Simulator praktikum pneumatic dua silinder katup solenoid tunggal sebagai berikut:

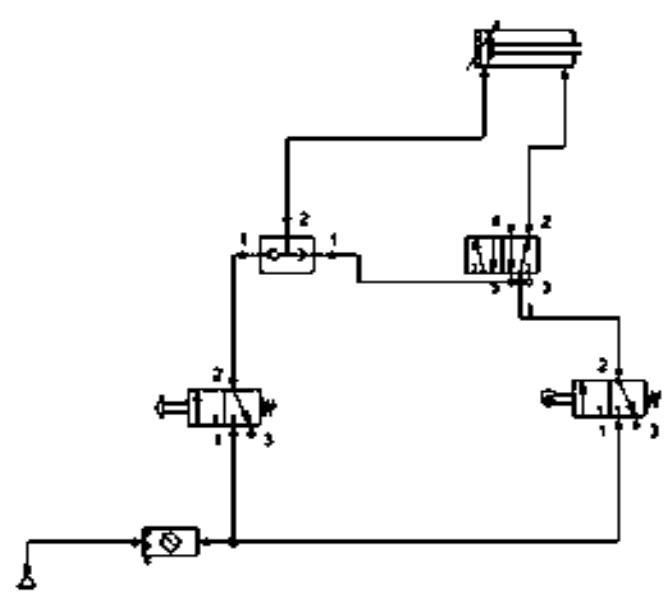

Gambar 2. Skema Rangkaian Pneumatic Dua Silinder Selenoid Tunggal.

\section{Pembuatan Kerangka}

Kerangka digunakan untuk merakit komponen pneumatic, lihat gambar 10.
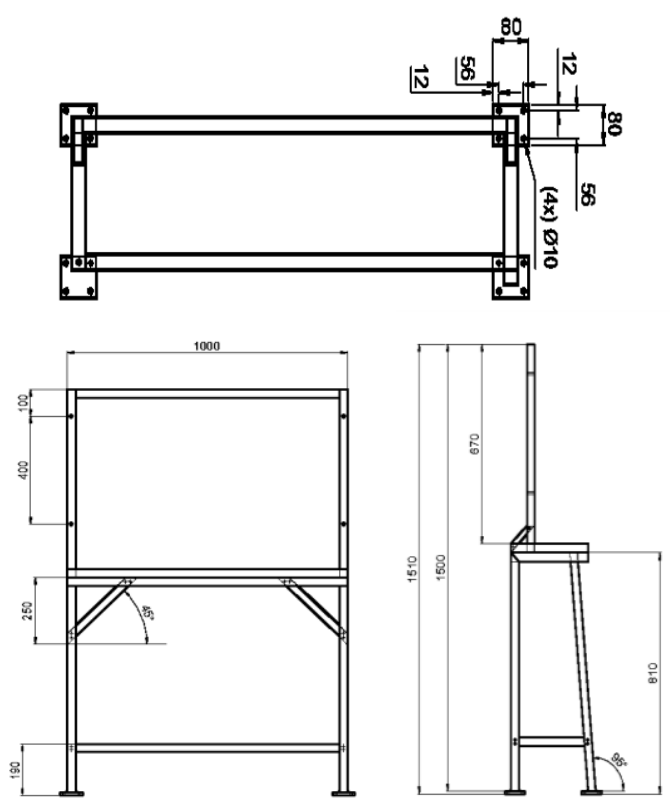

Gambar 3 Desain Rangka.

\section{Tahapan Pembuatan Alat}

Langkah-langkah dalam pembuatan dan perakitan meja alat Simulator pneumatic dua silinder katup solenoid ganda yaitu

1. Pemotongan besi siku sesuai ukuran;

2. Pengelasan pada besi untuk membuat meja alat;

3. Pembuatan lubang dan pemasangan besi siku yang telah di las;

4. Pemotongan papan kayu dan triplek melamin;

5. Tahap pemberian dempul dan pengamplasan; dan

6. Pengecetan kerangka meja alat.

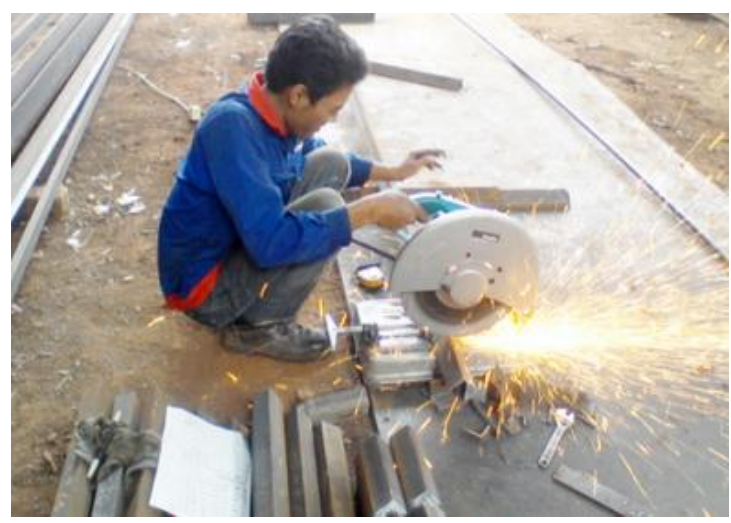

Gambar 4 Pemotongan Besi Siku

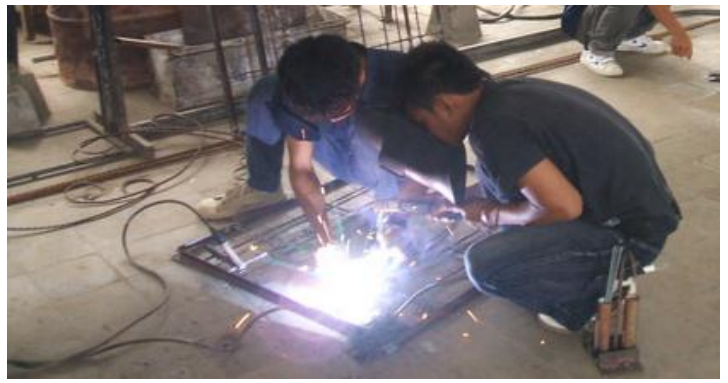

Gambar 5 Pengelasan Rangka

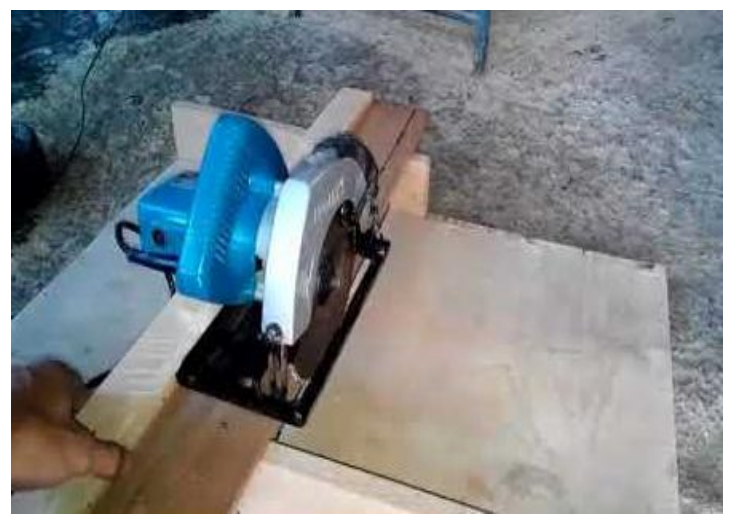

Gambar 6 Pemotongan dan Pemasangan Papan 


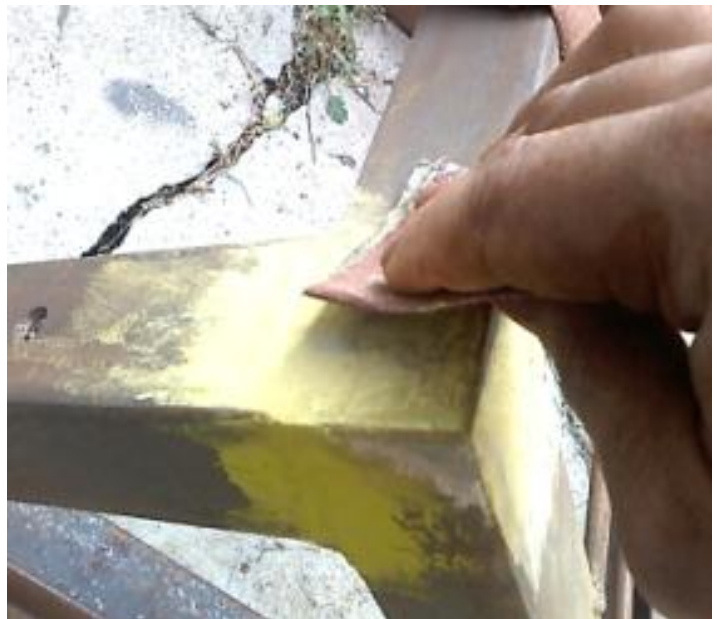

Gambar 7 Tahap Pemberian Dempul dan Pengamplasan

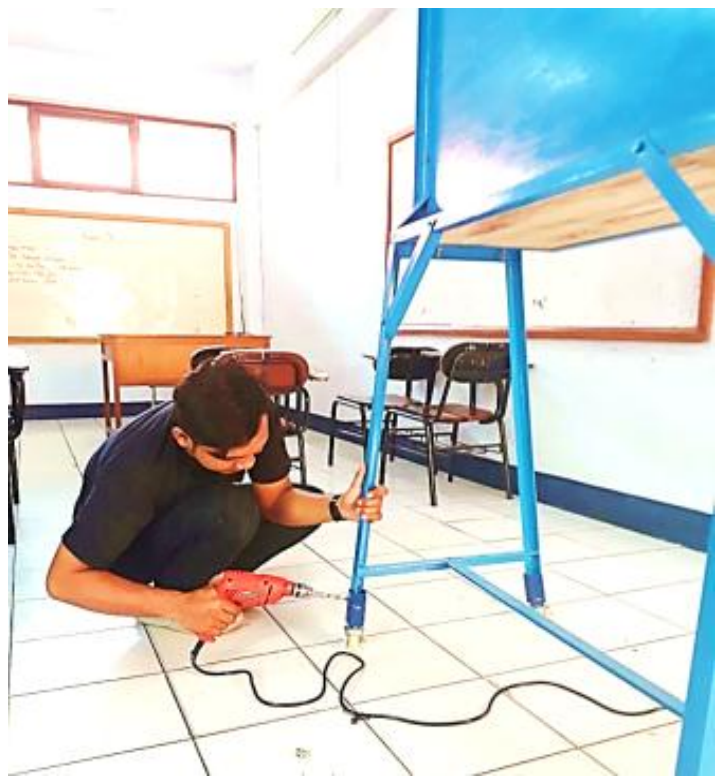

Gambar 8. Perakitan, Pengecetan Rangka dan Pemasangan Sepatu Roda.

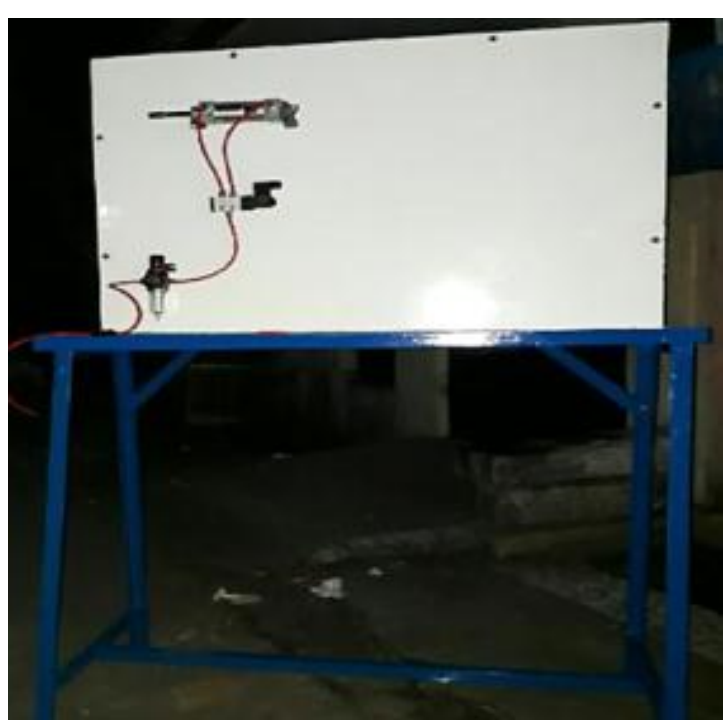

Gambar 9. Rangka Yang Sudah Siap dipasang Alat simulator.
3. ANALISA DAN PEMBAHASAN

1. Spesifikasi Alat Praktikum Pneumatic

a) Alat praktikum pneumatic ini hanya berbentuk simulator dan dapat digunakan untuk kerja praktek.

b) Alat praktikum pneumatic rangkaian pneumatic dua silinder katup selenoid Tunggal

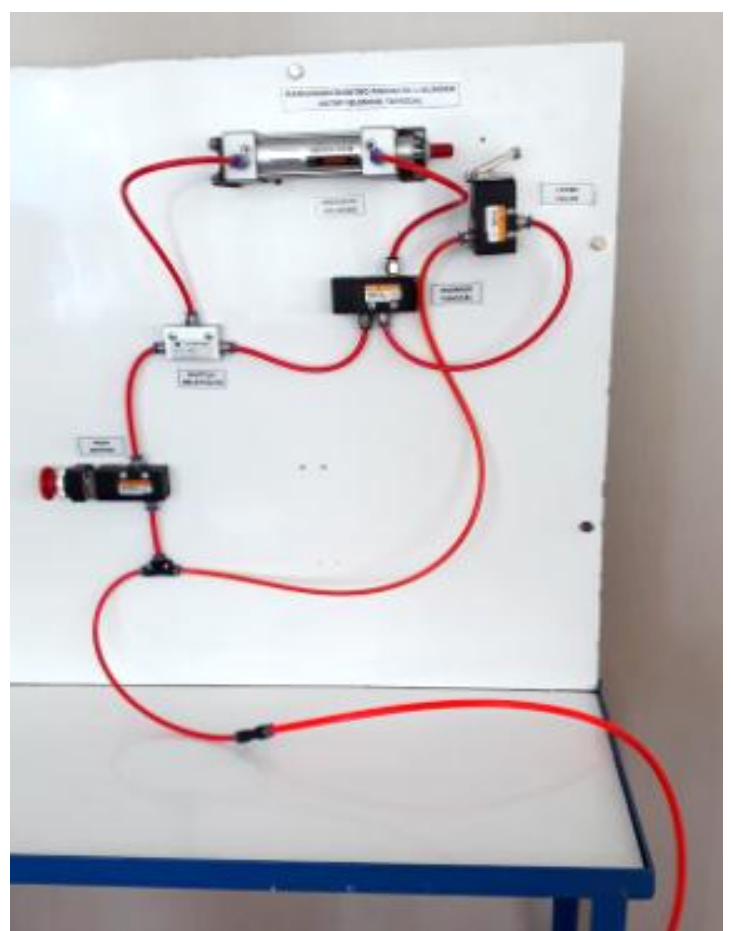

Gambar 9. Instalasi Pneumatic dua silinder katup selenoid tunggal.

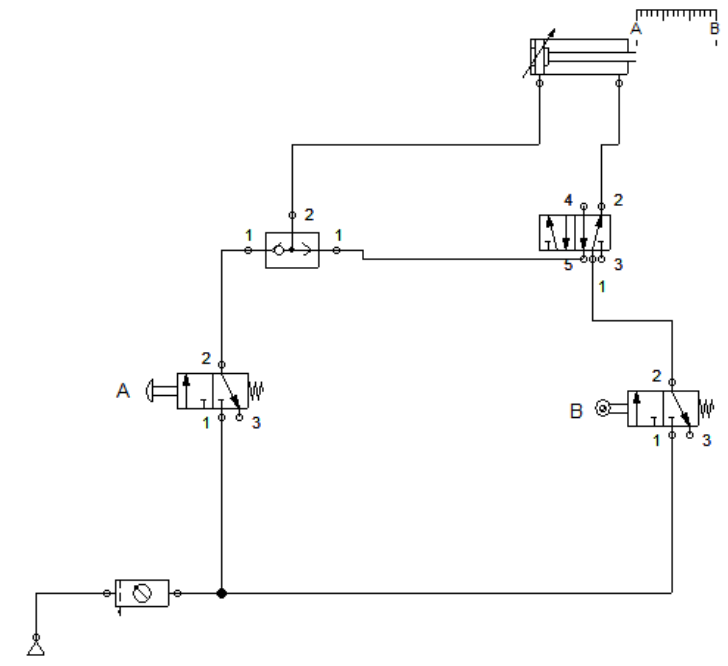

Gambar 10. Skema Pneumatic dua silinder katup selenoid tunggal. 


\section{Pengoprasian}

Langkah-langkah pengoprasian pada rangkaian pneumaticdua silinder katup solenoid tunggal sebagai berikut:

a) Menyiapkan Kompresor,

b) Sambungkan selang udara Pneumatic pada kompresor, lihat gambar 11 sebagai berikut:

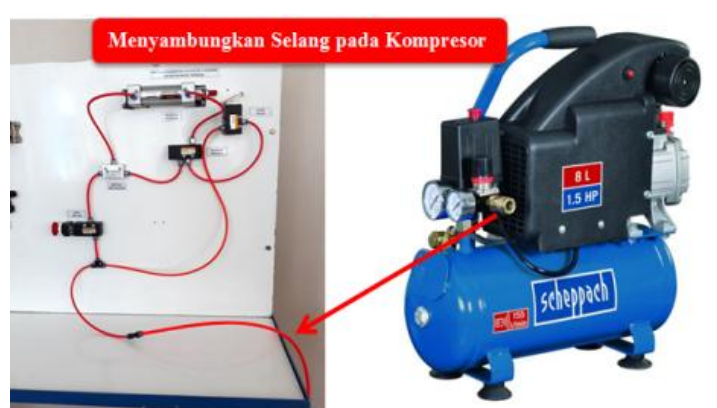

Gambar 11. Penyambungan selang udara Pneumatic pada kompresor.

Membuka Katup selang udara kompresor, lihat gambar 12 sebagai berikut:

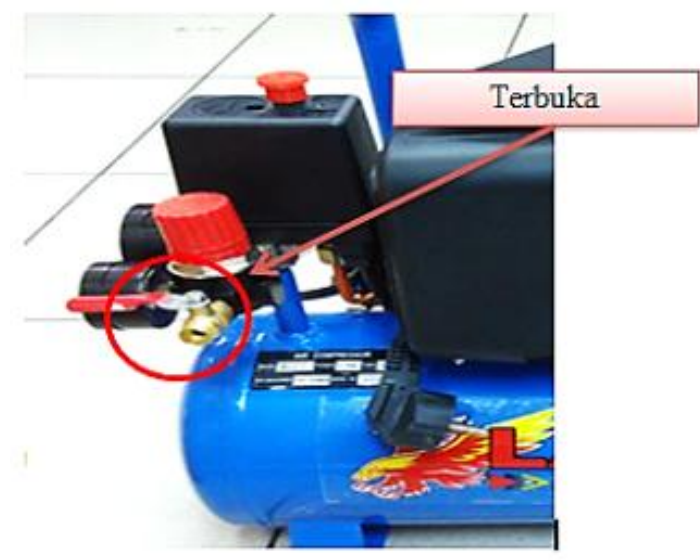

Gambar 12. Membuka Kran Udara.

Setelah tersambung selang pada kompresor dibuka pada kran angin pada kompresor, lalu atur tekanan udara yang diinginkan dengan cara memutar katup pada regulator. Kompresor akan mengalirkan udara kempa pada masing masing ke seluruh sistem Pneumatic.

\section{Perhitungan Pneumatic}

a) Perhitungan Gaya Tekan

Untuk mengetahui berapa beban yang harus di dorong.

$$
F=m \cdot g
$$

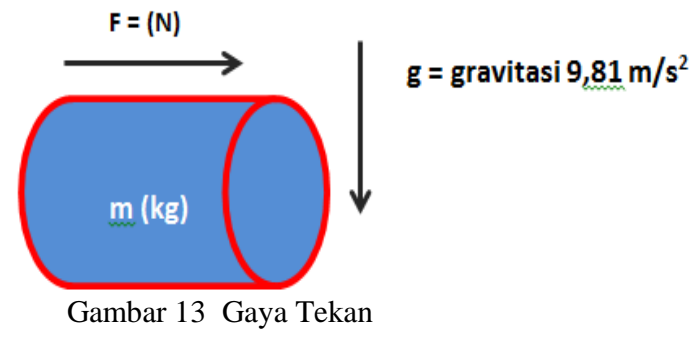

Dimana:

$\mathrm{F}=$ Gaya $(\mathrm{N})$

$m=$ Massa $(\mathrm{kg})$

$\mathrm{g}=\operatorname{gravitasi}\left(9,8 \mathrm{~m} / \mathrm{s}^{2}\right)$

b) Perencanaan Silinder Pneumatic

$$
\begin{aligned}
& (\mathrm{F}+\mathrm{R})=\mathrm{A} \times \mathrm{P} \\
& \text { atau } \\
& (\mathrm{F}+\mathrm{R})=\left(\frac{\pi}{4} \times D^{2}\right) \times \mathrm{P}
\end{aligned}
$$

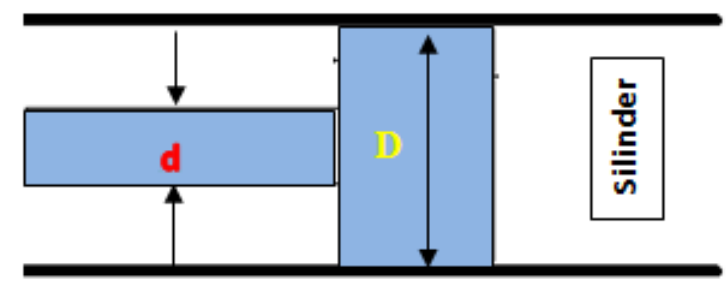

Gambar 12. Menentukan Silinder Pneumatic.

Dimana:

$\mathrm{A}=$ Luas silinder $\left(\mathrm{m}^{2}\right)$

$\mathrm{P}=$ Tekanan Kerja $\left(\mathrm{N} / \mathrm{m}^{2}\right)$

$\mathrm{F}+\mathrm{R}=$ Gaya tekan dan gesek yang terjadi

$\mathrm{D}=$ Diameter piston $(\mathrm{m})$

$\mathrm{d}=$ Diameter batang piston $(\mathrm{m})$

c) Perhitungan gaya pada Pneumatic

(1) Gaya efektif piston saat maju $\mathrm{F}_{(\text {maju })}=\mathrm{A} \times \mathrm{P}$

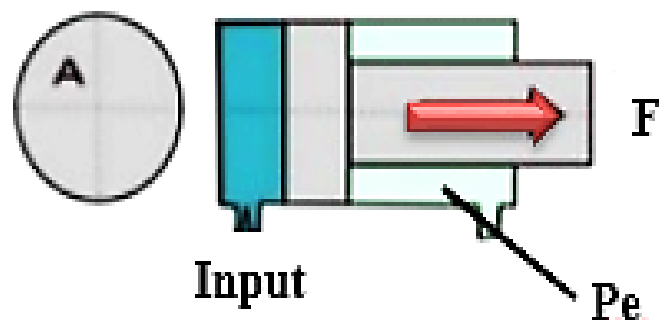

Gambar 15. Gaya Efektif Piston Saat Maju.

Dimana:

$\mathrm{F}=$ Gaya efektif piston saat maju $(\mathrm{N})$

$\mathrm{A}=$ Luas permukaan silinder Pneumatic $\left(\mathrm{m}^{2}\right)$

$\mathrm{A}=\left(\frac{\pi}{4}\left(\mathrm{D}^{2}\right)\right)=\left(\frac{3.14}{4}\left(\mathrm{D}^{2}\right)\right)$

(2) Gaya efektif piston saat mundur

$$
\mathrm{F}_{\text {(mundur) }}=\mathrm{A} \times \mathrm{P}
$$




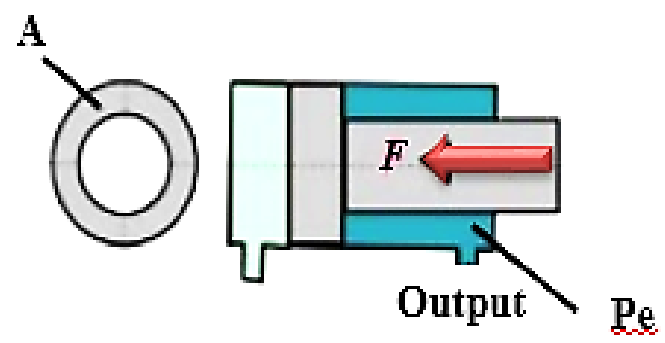

Gambar 16. Gaya Efektif Piston SaatMundur

Dimana:

$\mathrm{F}$ = Gaya efektif piston saatmundur $(\mathrm{N})$

A = Luas permukaan silinder Pneumatic $\left(\mathrm{m}^{2}\right)$

$$
\mathrm{A}=\left(\frac{\pi}{4}\right) \times\left(D^{2}-d^{2}\right)
$$

d) Konsumsi udara tiap langkah piston

(1) Konsumsi udara pada saat piston maju

$$
\mathrm{V}_{1}=\mathrm{p} \times\left(\frac{\pi}{4}\right) \times \mathrm{D}^{2} \times \mathrm{h}
$$

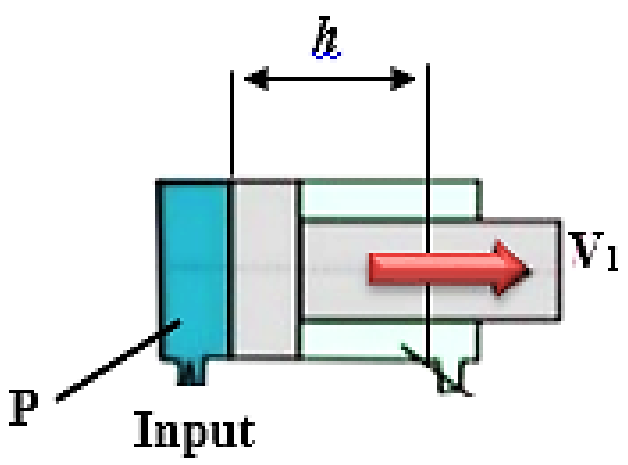

Gambar 17. Konsumsi Udara Saat Piston Maju.

Dimana:

$\mathrm{V}=$ Konsumsi udara saat piston bergerak maju $(\mathrm{m} / \mathrm{s})$

$\mathrm{P}=$ Tekanan kerja untuk Pneumatic $\left(\mathrm{N} / \mathrm{m}^{2}\right)$

$\mathrm{D}=$ Diameter piston $(\mathrm{m})$

$\mathrm{h}=$ Panjang langkah $(\mathrm{cm})$

(2) Konsumsi udara saat piston mundur

$$
\mathrm{V}_{2}=\mathrm{P} \times\left(\frac{\pi}{4}\right) \times\left(\mathrm{D}^{2} \times \mathrm{d}^{2}\right) \times \mathrm{h}
$$

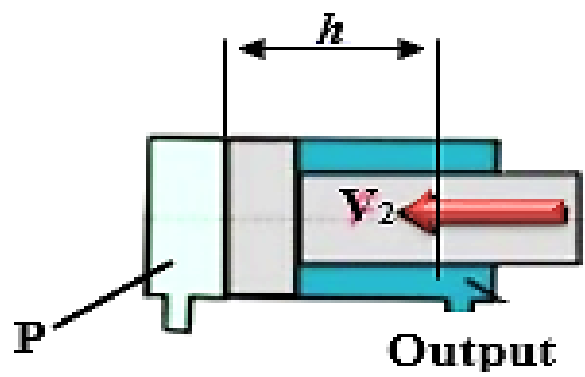

Gambar 18. Konsumsi Udara Saat Piston Mundur.

Dimana:

$\mathrm{V}=$ Konsumsi udara saat piston bergerak mundur $(\mathrm{m} / \mathrm{s})$

$\mathrm{P}=$ Tekanan kerja untuk Pneumatic $\left(\mathrm{N} / \mathrm{m}^{2}\right)$

$\mathrm{D}=$ Diameter piston $(\mathrm{m})$

$\mathrm{h}=$ Panjang langkah $(\mathrm{cm})$

(e) Perhitungan Daya Kompresor Debit kompresor:

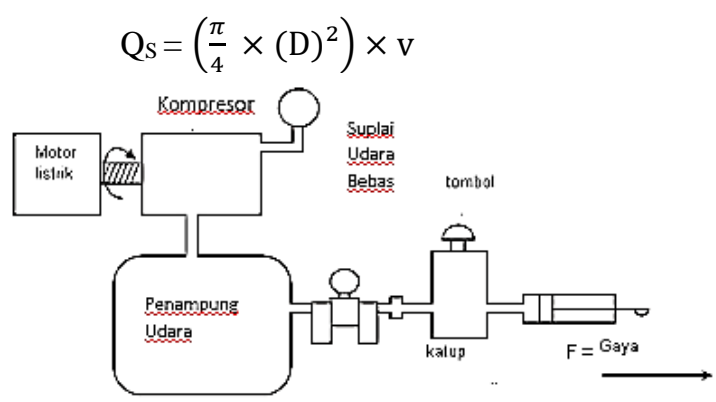

Gambar 19. Daya Kompresor

Dimana:

$\mathrm{Q}_{\mathrm{s}}=$ Debit kompresor (liter/menit)

$\mathrm{D}=$ Diameter silinder $(\mathrm{mm})$

$\mathrm{v}=$ Kecepatan piston $(\mathrm{mm} / \mathrm{menit}$ atau $(\mathrm{mm} /$ detik)

\section{KESIMPULAN}

Dari hasil rancang bangun alat praktikum pneumatic, maka dapat disimpulkan sebagai berikut

1. Rancang bangun alat praktikum pneumatic dua silinder katup solenoid Tunggal ini hanya sebagai bentuk simulator/alat praga dan digunakan untuk kegiatan belajar khususnya di dunia pendidikan, untuk meningkatkan imajinasi dan penerapan ilmu dalam dunia kerja.

2. Udara kempa disalurkan dengan membuka katup pada service unit, (menggunakan tekanan udara yang telah di tentukan), kemudian menekan tombol katup pneumatic (katup pengarah) hingga udara kempa masuk ke dalam tabung pneumatic (silinder pneumatic kerja tunggal) dan akhirnya piston bergerak maju.

3. Bahan Utama pembuatan Rancang bangun alat simulator silinder pnumatik tipe BSC $32 \times 502$ buah, Selenoid tipe V5222-084 pressure 0,15-0,8 Mpa 2 buah, Shuttle Valve type Ks-02 satu buah, Push Button tipe M32-08S1B pressure: 0-0,8 Mpa satu buah, Lever Valve tipe M32-08S2 satu buah, Regulator ukuran 14 satu buah, selang $6 \mathrm{~mm}$ $6 \mathrm{~m} 2$ buah,, Nepel ukuran $6 \mathrm{~mm} 26$ buah 
dan Elektrik Selenoid 4V10-08 Pressure 1,5-8kg 1 buah.

\section{DAFTAR PUSTAKA}

Al Antoni Akhmad. Perancangan Simulasi Sistem Pergerakan Dengan Pengontrolan Pneumatik Untuk Mesin Pengamplas Kayu Otomatis. Jurnal Rekayasa Sriwijaya, Vol. 18 No 3 Nopember 2009. ISSN 0852-5366

DRS.Wirawan, MT dan DRS. Pramono MT, 2011. Pneumatik dan Hidrolik. Semarang: Eduadus.

Martino, 2014, Analisa dan Perhitungan Sistem Pneumatik Pada Penggunaan Miniatur Furnitur Multifungsi, Skripsi, Jurusan Teknik Mesin Fakultas Teknik, Jakarta.

Muhammad Subhan, Ari Satmoko.Penentuan Dimensi dan Spesifikasi Silinder Pneumatik Untuk Pergerakan Tote Iradiator Gamma Multiguna Batan. Jurnal Perangkat Nuklir, Vol. 10 No 2 November 2016. ISSN 1978-3515

Noor Hudallah. Rancang Bangun Sistem Pneumatik Untuk Pengembangan Modul-Modul Gerak Otomatis Sebagai Media Pembelajaran. JurnalTeknik Elektro, Vol. 2 No 1 Januari-Juni 2010.
Windarta. Perancangan Mesin Pembersih Untuk Part Internal Alat Berat Dengan Sistem Pneumatik. Jurnal Teknik Mesin, Vol. 10 No 1 2006.ISSN 2549-9645.

Riccy Kurniawan. Rekayasa Rancang Bangun Sistem Pemindahan Material Otomatis Dengan Sistem Elektro Pneumatik. Jurnal Ilmiah Teknik Mesin CAKRAM Vol.2 No.1 Juni 2008 (42-47).

Legisnal Hakim. Analisa Sistem Pneumatik Untuk Penggerak Alat Panen Kelapa Sawit. Jurnal Analisa Sistem Pneumatik Vol.2 No.4 April 2005.

Sularso, dan Kiyokatsu Suga.1987. Dasar Perencanaan dan Pemilihan Elemen Mesin. Jakarta, PT. PRANDNYA PARAMITA

Perhitungan Dan Perencanaan Pneumatic Faqih Udin Mubarok - 2011

https://www.scribd.com/document/34903772 2/Perhitungan-Dan-PerencanaanKomponen-Pneumatic

Sistem Pneumatik Dalam industri - Temon Soejadi - 2014 https://temonsoejadi.wordpress.com/201 4/11/13/sytem-pneumatic-dalam-duniaindustri. 